\title{
The Effect of Abdominal Subcutaneous Fat Tissue Thickness in Pelvic Trauma
}

\author{
Abdominal Subkutan Yağ Doku Kalınlığııı Pelvik Travma Üzerine Etkisi
}

\author{
Yeliz Aktürk, Serra Özbal Güneș \\ University of Health Sciences, Dışkapı Yıldırım Beyazıt Training and Research Hospital, Department of Radiology, Ankara, Turkey
}

\begin{abstract}
Aim: Obesity is a very important health problem throughout the world. The effect of obesity on trauma-related injuries is being investigated in contemporary literature. The weight of the patient is said to increase complications with the severity of trauma. The effect of obesity on pelvic trauma has been investigated in various studies in the literature. However, no similar study investigating the effect of obesity on acetabular fractures and accompanying femoral head fractures has been found.

Our aim in this study is to determine the incidence of accompanying femoral head fractures in adult cases with acetabulum fracture and to investigate whether abdominal subcutaneous fat tissue thickness has an effect on this co-existence.
\end{abstract}

Material and Method: Pelvic CT scans taken in our hospital due to trauma were retrospectively reevaluated and cases with acetabulum fracture were detected. These cases were divided into two separate groups: those with isolated acetabulum fractures and those with acetabulum-and accompanying femoral head fractures. Abdominal subcutaneous fat tissue thicknesses of all cases were measured via CT scan. It has been investigated whether there is a statistically significant difference between the two groups in terms of subcutaneous fat tissue thickness.

Results: A total of 95 acetabular fractures were detected. In 22 cases (23.2\%), femoral head impaction fracture was present in addition to acetabulum fracture. In the remaining 73 cases (76.8\%), the femur head was normal. The average abdominal subcutaneous fat tissue thickness was $24.4( \pm 9.2) \mathrm{mm}$ in isolated acetabular fracture cases, and $30.4( \pm 8) \mathrm{mm}$ in cases with acetabulum and accompanying femoral head fractures. Abdominal subcutaneous fat thickness was significantly higher in patients with femoral head fracture in addition to acetabulum ( $p=0.006)$.

Conclusion: It's possible to say that abdominal subcutaneous fat accumulation increases the risk of femoral head fracture development by increasing the severity of trauma, thus increasing the morbidity.

Key words: acetabulum; femur fracture; subcutaneous fat

Yeliz Aktürk, University of Health Sciences, Dışkapı Yıldırım Beyazıt Training and Research Hospital, Department of Radiology, Ankara, Turkey

Tel.05363515536Email.yelizakturk@yahoo.com

Geliş Taribi: 08.03.2018 • Kabul Taribi: 10.07.2018
ÖZET

Amaç: Obezite dünya genelinde çok önemli bir sağlık problemidir. Güncel literatürde travmalara bağı hasara obezitenin etkisi araștırılmaktadır. Hasta kilosunun, travmanın șiddeti ile beraber komplikasyonları arttırdığı söylenmektedir. Obez hastalarda travma sonrası ekstremite kırıklarının daha sık görüldügü öne sürülmektedir. Literatürde pelvik travmalara obezitenin etkisi çeșitli çalıșmalarla araștırılmıștır. Ancak asetabuler fraktür ve eșlik eden femur bașı fraktürlerine obezitenin etkisini araștıran benzer bir çalıșma bulunamamıștır.

Bu çalıșmada amacımız; asetabulum fraktürü olan erișkin olgularda, eșlik eden femur bașı fraktürünün görülme sıklığını belirlemek ve bu birlikteliğe abdominal subkutan yağ doku kalınlığının etkisi olup olmadığını araștırmaktır.

Materyal ve Metot: Travma nedeniyle hastanemizde çekilen pelvik tomografiler retrospektif olarak yeniden değerlendirilerek, asetabulum fraktürü olan olgular saptandı. Bu olgular, izole asetabulum fraktürü olanlar ve asetabulum ile femur bașı fraktürü birlikte görülenler olarak iki ayrı gruba ayrıldı. Tüm olguların abdominal subkutan yağ doku kaIınlıkları tomografik olarak ölçüldü. İki grup arasında subkutan yağ doku kalınlığı açısından istatistiksel anlamlı farkılık olup olmadığı araștırıldı.

Bulgular: Toplam 95 olguda asetabuler fraktür bulundu. Olguların 22 'sinde $(\% 23,2)$ femur bașı impaksiyon fraktürü eșlik etmekteydi. Kalan 73 olguda $(\% 76,8)$ femur bașı normaldi. Ortalama abdominal subkutan yağ doku kalınlığı; izole asetabuler fraktür olan olgularda $24,4( \pm 9,2) \mathrm{mm}$, eșlik eden femur bașı fraktürü olan olgularda 30,4 (₫8) $\mathrm{mm}$ idi. Abdominal subkutan yağ doku kalınlığı, femur bașı ve asetabulum fraktürü birlikte görülen olgularda istatistiksel olarak anlamlı derecede daha fazlaydı $(p=0,006)$.

Sonuç: Asetabulum fraktürüne ek olarak femur bașı fraktürü izlenen olgularda abdominal subkutan yağ doku kalınlığı belirgin daha fazla bulunmuștur. Abdominal subkutan yağ birikiminin, travmanın șiddetini arttırarak femur bașı fraktürü gelișimi riskini, dolayısıla morbiditeyi arttıran bir risk olușturduğu söylenebilir.

Anahtar kelimeler: asetabulum; femur fraktürü; subkutan yağ

\section{Introduction}

The pattern and severity of a post-traumatic injury depend on the complex relationship between biomechanical factors such as the velocity of trauma, the use of decelerators (e.g. seat belts), and the intensity of the 
impact. In addition, characteristics such as height and weight of the human body play an important role ${ }^{1}$. The effect of body mass on the traumatic injury pattern was assessed through different studies for adults and children. The general conclusion of these studies is that obesity is predisposed to various injury patterns but does not necessarily increase the cumulative severity of the injury ${ }^{2-5}$. Some studies, on the contrary, suggest that a high body mass index (BMI) increases the energy dispersed during trauma, thereby increasing the risk of injury and death in severe traumas ${ }^{6}$.

The incidence of hip fractures has increased over the last decades ${ }^{7}$. Although the cause of this increase is not known, it can be explained in part by a more sedentary lifestyle and a change in the weight-bearing parts of the thigh bones ${ }^{8}$. Acetabular fractures have been reported in about $50 \%$ of femoral head fractures 9 . Femoral head fractures can lead to severe morbidity and multiple complications such as avascular necrosis, osteoarthritis, peripheral nerve damage, heterotopic bone formation ${ }^{10}$. The incidence of femoral head fracture in acetabulum posterior wall fractures is between 18 and $63 \%$. The overall incidence of both femoral head and acetabulum fractures has been reported to be $11 \%$ after excluding posterior wall fractures. In acetabular fractures associated with femoral head fractures, hip arthroplasty is more commonly needed ${ }^{11}$. There are several publications in the literature investigating the coexistence of femur head and acetabular fractures. To our knowledge, however, there is no similar study investigating the effect of obesity on the rate of femoral head fracture accompanying to acetabular fractures.

The purpose of this study is to investigate whether subcutaneous fat tissue thickness has an effect on the rate of femoral head fracture in trauma patients. The study examined whether the frequency of accompanying femoral head fracture changes as the subcutaneous fat tissue thickness increases in cases with acetabular fractures.

\section{Material and Method}

\section{Ethics}

This study has been approved by the ethics committee. The study was conducted in accordance with the principles of the Declaration of Helsinki.

\section{Study design}

Computerized tomography (CT) scans of patients who applied to our hospital due to trauma between

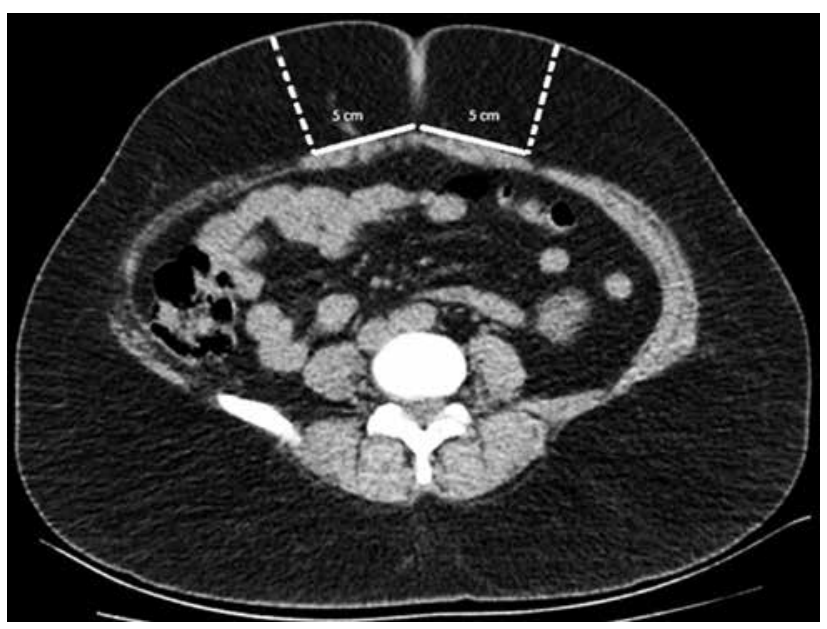

Figure 1. Axial CT image, the measurement was performed as standard, $5 \mathrm{~cm}$ lateral to umbilicus (continuous lines), bilaterally, and in millimeters. The arithmetic mean of the values (dashed lines) from the right and left measurements was calculated.

June 2017 and November 2017 were retrospectively reevaluated. Adult cases with acetabular fracture in pelvic CT were included in the study. Abdominal subcutaneous fat tissue thickness of all acetabular fracture cases was measured from axial sections. The measurement was performed as standard, $5 \mathrm{~cm}$ lateral to umbilicus, bilaterally, and in millimeters (Figure 1). The arithmetic mean of the values from the right and left measurements was calculated ${ }^{12}$.

Among the cases with acetabular fractures, those with accompanying femoral head fractures were noted. Patients were divided into two separate groups: cases with isolated acetabulum fractures and cases with acetabulum-and accompanying femoral head fractures. Statistical analysis was performed to investigate the presence of a difference in abdominal subcutaneous fat tissue thickness between the two groups.

In addition, all acetabular fractures were typologized according to the Judet-Letournel classification and the most common types of fractures were identified. Pediatric cases were excluded from the study.

\section{Imaging parameters}

All CT scans were performed using the same 128-slice CT device (Optima CT660, General Electric Healthcare Systems, Milwaukee, USA), at a dose appropriate for the bone structure, with sections of 2.5 $\mathrm{mm}$ thickness and according to the standard imaging protocol. Axial, coronal and sagittal images as well 
as three dimensions (3D) reconstructed images were evaluated by a radiologist with 10 years of tomography experience in the same workstation.

Statistical analyses were performed using Statistical Package for the Social Sciences 15.0 (SPSS Inc. ; Chicago, IL, USA). Non-parametric parameters were analyzed using the Mann-Whitney $U$ test. It was confirmed when a binary logical regression analysis was carried out. Data were shown as mean \pm standard deviation or median (min-max), where applicable. A p value $<0.05$ was considered statistically significant.

\section{Results}

As a result of pelvic CT scans taken between June 2017 and November 2017, a total of 95 acetabular fractures were detected. The ages of the patients ranged from 18 to 88 (mean: 48.2$) .36$ of them were female $(38 \%)$ and 59 were male $(62 \%)$. All the cases had a motor vehicle trauma. The average abdominal subcutaneous fat tissue thickness of all cases was $25.8 \mathrm{~mm}$.
In 22 cases (23.2\%), femoral head impaction fracture was present in addition to acetabulum fracture. The ages of these 22 patients ranged from 37 to 85 (mean: 49.6). 18 of them were male. 12 of femoral head-and acetabulum fractures were on the right side and 10 of them on the left side.

The average abdominal subcutaneous fat tissue thickness was $24.4( \pm 9.2) \mathrm{mm}$ in isolated acetabular fracture cases, and $30.4( \pm 8) \mathrm{mm}$ in cases with acetabulum and accompanying femoral head fractures. Abdominal subcutaneous fat thickness was significantly higher in patients with femoral head fracture in addition to acetabu$\operatorname{lum}(p<0.05)$. When two groups were compared for the age there was not any significant difference $(\mathrm{p}=0.56)$.

Baseline characteristics of patients with and without femoral head fracture summarized in Table 1.

All acetabular fractures were typologized according to the Judet-Letournel classification (Table 2). The most common types according to this classification were

Table 1. Baseline characteristics of patients with and without femoral head fracture

\begin{tabular}{lcc}
\hline & Femoral head fracture present $(\mathrm{n}=22)$ & Femoral head fracture absent $(\mathrm{n}=73)$ \\
\hline Age (mean \pm SD) & $49.6 \pm 18.6$ & $48.2 \pm 21.4$ \\
Gender, $\mathrm{n}(\%)$ (male/female) & $18(81.8 \%) / 4(18.2 \%)$ & $45(61.6 \%) / 28(38.4 \%)$ \\
Mechanism of injury, $\mathrm{n}(\%)$ & & $42(57.5 \%)$ \\
Hit a pedestrian & $9(40.9 \%)$ & $23(31.5 \%)$ \\
Multiple vehicle collisions & $7(31.8 \%)$ & $8(11 \%)$ \\
Single-car accidents & $6(27.3 \%)$ & \\
\hline
\end{tabular}

Table 2. The distribution of all acetabular fractures according to the Judet-Letournel classification and location, and accompanying femoral head fracture frequency

\begin{tabular}{|c|c|c|c|}
\hline & Femoral head fracture $(+)$ & Femoral head fracture (-) & Total \\
\hline Judet-Letournel Classification & $\mathrm{n}=22$ & $n=73$ & $\mathrm{n}=95$ \\
\hline Anterior wall & 0 & 13 & 13 \\
\hline Anterior column & 1 & 29 & 30 \\
\hline Posterior column & 0 & 6 & 6 \\
\hline Posterior wall & 4 & 5 & 9 \\
\hline Transverse fracture & 2 & 2 & 4 \\
\hline T shape fracture & 2 & 2 & 4 \\
\hline Transverse + posterior wall & 1 & 2 & 3 \\
\hline Posterior column + posterior wall & 0 & 2 & 2 \\
\hline Anterior column + posterior hemitransverse & 3 & 2 & 5 \\
\hline Both columns & 9 & 10 & 19 \\
\hline \multicolumn{4}{|l|}{ Acetabular Fracture Locations (\%) } \\
\hline Anterior (45.3\%) & 1 & 42 & 43 \\
\hline Posterior (15.8\%) & 4 & 11 & 15 \\
\hline Complex (38.9\%) & 17 & 20 & 37 \\
\hline
\end{tabular}




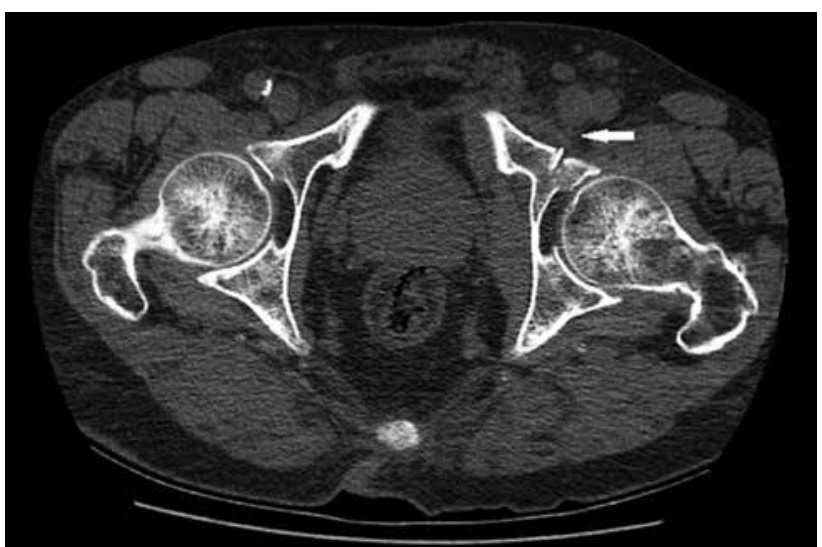

Figure 2. Axial CT image of the anterior column fracture (white arrow), one of the most common fracture types, when our cases were evaluated according to the Judet-Letournel classification.

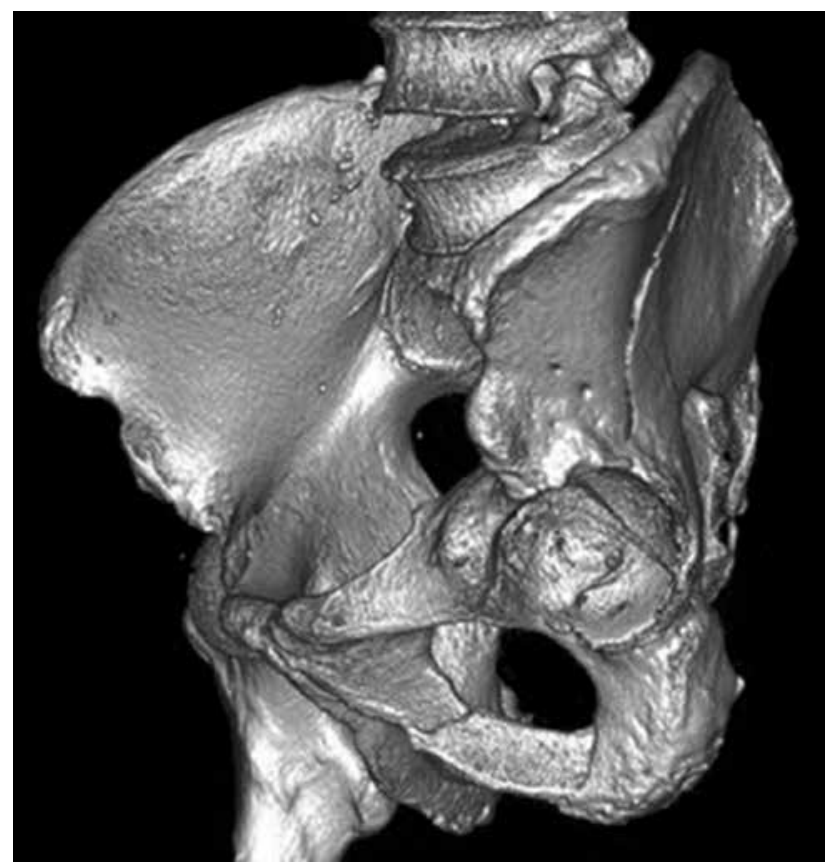

Figure 3. 3D reconstruction image of double column fracture, with break in obturator ring and extension into iliac wing.

fractures in anterior column (31.6\%) and both columns (20\%). When assessed independently from the subcutaneous fat tissue thickness, the ratio of acetabular fractures accompanied by femoral head fracture was higher in combination types affecting both the anterior and posterior columns and in the types affecting only the posterior column. In the acetabular fracture types affecting the anterior column, the coexistence rate of femoral head fracture was significantly lower and the difference was statistically significant.

Figures 2, 3 and 4 show CT images of the sample cases.

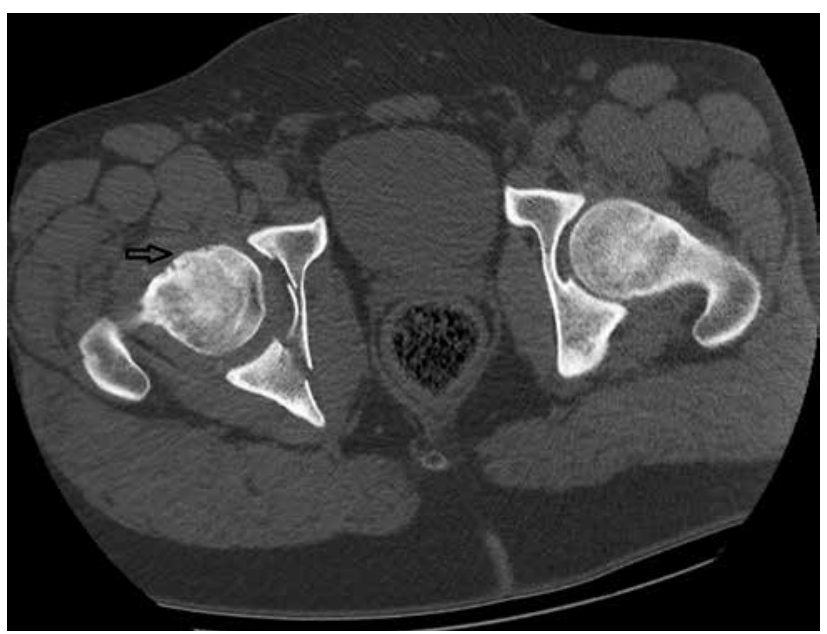

Figure 4. In the axial image passing through the acetabulum level, fracture at the femoral head (open arrow) in addition to the acetabulum fracture.

\section{Discussion}

Obesity is a chronic metabolic disease that becomes epidemic and is a major health problem worldwide ${ }^{13-15}$. Due to its increasing prevalence, it is now accepted as a global pandemic ${ }^{16-18}$. According to NHANES (United States National Health and Nutrition Examination Survey) data for 2011-2012, more than one third of adults are obese ${ }^{18}$. With the worldwide increase in obesity, an important debate has started about whether its effect on skeletal health is destructive or beneficial ${ }^{19}$.

Kim et al. $s^{20}$ study reported that extremity fractures are significantly higher in obese children compared to nonobese children. Davidson et al.'s ${ }^{21}$ study, on the other hand, revealed that the risk of upper extremity fracture in obese children was 1.7 times higher than in non-obese children. Besides, Pomerantz et al. ${ }^{22}$ reported a significantly higher risk of lower extremity fracture in obese children. In a study conducted by Backstrom et al. ${ }^{2}$ in 356 pediatric cases, a higher Injury Severity Score (ISS) values were reported in obese pediatric patients with lower extremity long bone fractures compared to nonobese patients. The same study observed more severe injuries and a higher Abbreviated Injury Scale (AIS) in each major body part (head and neck, chest, abdomen and extremities), and revealed that pelvic fractures and spinal column injury were more common in obese patients. Backstrom et al.'s study discovered that the obese patients have a greater need for operation in case of femoral fractures. A similar finding has been reported in Rana et al.' ${ }^{3}$ study of 1.314 pediatric trauma cases. It has been suggested that greater need for operation may indicate more severe fracture patterns. 
In a study conducted on 149.817 pediatric cases, Witt et al. ${ }^{23}$ reported that upper and lower extremity injuries were significantly more frequent, and that head, thorax, abdomen, and spinal injuries are observed less frequently in patients with a higher BMI. Another study conducted by Vaughan et al. ${ }^{24}$ on 1.012 pediatric cases found that ISS and abdominal AIS were significantly higher in obese patients when compared to non-obese patients. In this study, severe hepatic damage was more common in obese patients, but there was no difference in terms of femoral fracture, costa fracture, pleural injury, and brain damage.

One reason for the more frequent occurrence of extremity fractures in obese children may be their higher exposure to risky situations in terms of trauma. Most of the studies found that bone mineral content was normal or increased in obese children ${ }^{20,25}$. However, the general opinion is that obese children have a relatively decreased bone mass compared to the bone size and body weight $^{20,26}$. Dual energy X-ray absorptiometry (DEXA) studies have shown that obese children have a relatively low bone area and bone mass compared to their normal weight peers, although they have a higher absolute bone density considering their chronological age ${ }^{26}$. Increased kinetic energy associated with increased body mass can lead to more severe damage patterns ${ }^{1,2}$. An increased mass associated with obesity may lead to a higher energy and power dispersion in the lower extremities after trauma ${ }^{27}$. Larger individuals are at greater risk of injury, as the energy of the impact is directly proportional to mass and speed ${ }^{15}$. Furthermore, less or looser use of the seatbelt in obese children can cause more damage in case of motor vehicle accidents ${ }^{2,27}$.

In adults, on the other hand, the findings differ from the children. According to the studies done on adults, the total body fat mass and the areal bone-mineral densitometry (BMD) measured by DEXA show a positive correlation $^{19}$. Low weight or low BMI is a well-known risk factor for fracture development in the adult population. That is, there appears to be a protective effect of high $\mathrm{BMI}^{20,28,29}$. However, our results contradict with this view. According to our study, the increase in subcutaneous fat tissue thickness may have an effect on the development of femoral head fracture accompanied by acetabulum fracture.

A meta-analysis of 60.000 women and men, including twelve prospective community-based cohort studies, showed that total fractures, osteoporotic fractures and hip fractures were inversely related to BMI. In all fractures, age-related fracture irrespective of BMD was reported to increase with low $\mathrm{BMI}^{29}$.

The study conducted by Arbabi et al. ${ }^{1}$ on 189 adult trauma patients revealed that mortality and the severity of lower extremity injuries increased in obese patients. In this study, however, lower ISS and abdominal AIS scores were found in overweight patients. Based on this finding, the authors suggested that increased adipose tissue associated with obesity may cause dispersion of energy during trauma and may provide a protective effect against severe injury, especially in abdominal traumas (cushion effect). Conversely, according to our study, the increase in subcutaneous fat tissue thickness poses a risk for femoral head fracture development. In obese patients, the energy transfer and rate increase directly proportional to body weight at the time of trauma may explain the outcome of our study.

In the extensive community-based study conducted by Joakimsen et al. ${ }^{30}$, low BMI was suggested to be a risk factor for low-energy fractures in middle-aged women and men. It has been reported that weight-gaining men have decreased hip fracture risk, while women who gain weight are reported to have decreased lower extremity fracture risk. The analyzes conducted in this study revealed that all low-energy fractures in women had a statistically significant relationship with BMI. In men, on the other hand, a similar relationship was identified, albeit not statistically significan. The weak protective effect of weight gain, which is reported by the study of Joakimsen et al., is also compatible with the work of Cummings et al. ${ }^{31}$.

Recent studies suggest that the effect of obesity on bone fractures in adults may be specific to the body part. For example, although obesity appears to be protective for vertebral fractures, it has been reported to increase the risk of humeral fractures as well as ankle fracture frequency and severity $y^{19,32,33}$. However, it is unclear whether this is due to mechanical instability associated with the power increase or due to regional decline in bone mass associated with overweight ${ }^{19}$.

BMI can affect fracture risk in different ways ${ }^{30}$. Body mass correlates positively with bone mass ${ }^{30,34}$. Even after the addition of the fracture risk measured by BMD, low BMI is a significant risk factor for hip fracture. Although the mechanism is not completely known, muscle weakness, protein or vitamin D deficiency, or reduced protective tissue around the large trochanter may be effective ${ }^{29}$. Besides, the body mass correlates 
with the amount of soft tissue that protects the skeleton structure. This correlation is particularly important for the hip ${ }^{35}$. Although this finding seems to contradict with our study, our study measured the subcutaneous fat thickness at the level of the anterior abdominal wall, not around the hip. Fat accumulation at the level of the abdomen or obesity may cause trauma-induced concussions or injuries occur with higher energy and with increased damage severity.

The authors suggest that this poor protective effect of weight gain is lost due to increased risk of cardiovascular disease, hypertension and diabetes ${ }^{29,30}$. Conducted studies also suggest that obesity may be associated with trauma-related mortality ${ }^{15}$. In other words, obesity is an independent risk factor for mortality and morbidity related to high-energy trauma ${ }^{36}$. Decrease in lung volume and compliance is more common in obese patients. Deep vein thrombosis, gastroesophageal reflux and insulin resistance are also more common ${ }^{37}$. Thus, obesity in trauma patients is reported to lead to increased complications ${ }^{18}$. The incidence of pulmonary and renal complications is higher in obese patients ${ }^{36}$. Obese trauma patients have a greater need for mechanical ventilation and a higher incidence of multiple organ failure, and they spend a longer time in intensive care ${ }^{15,18}$. Furthermore, some studies have suggested that trauma may exacerbate the side effects related to critical illnesses in obese patients by increasing the persistent inflammatory response $^{18}$. Surgical procedures may become difficult and the diagnostic sensitivity of radiological imaging may be reduced due to obesity ${ }^{37}$. The study conducted by Ryb et al. ${ }^{38}$ on 1.615 adult patients discovered that reported increased severity of damage in overweight patients. In a study of 382 adult patients, on the other hand, Morris et al. ${ }^{36}$ have found that the risk of obesity-related complications increases significantly in trauma cases with operative and non-operative pelvic injuries. According to some authors, increased mortality is not due to higher trauma injury, but rather due to the more difficult posttraumatic care in obese patients and other comorbidities associated with obesity ${ }^{1}$.

With all these factors in mind, patients should be advised to be normal weight. One should emphasize that leanness is a risk factor for hip fractures rather than focusing on the view that increased body fat content may be protective ${ }^{29}$.

When evaluated in terms of location and independently from subcutaneous fat tissue thickness, fractures affecting posterior segment of acetabulum were more frequently accompanied by femoral head fracture and this finding is consistent with the literature.

\section{Study limitations}

Only adult cases were included in our study because of the inadequate number of pediatric cases. The small number of patients is also one of the limitations of our study. Furthermore, because the height and weight values of the patients were inaccessible, BMI could not be used as a comparison parameter. Therefore, we investigated the effect of abdominal subcutaneous fat tissue thickness on femoral head fracture rather than obesity, which is defined by increased BMI. Studies in the literature suggest that height increase is positively related to low-energy fractures. Hip fractures are more common in tall people compared to short people (30). BMI also contains the height parameter. The fact that we only used subcutaneous fat tissue thickness as an independent parameter in our study leads to the elimination of the height factor in the studies investigating the relationship between fracture and BMI. In addition to these, the severity, direction, shape of the trauma and the characteristics of the patient other than the subcutaneous fat tissue thickness (age, sex, drug use that may affect BMD, other accompanying clinical conditions such as osteoporosis) were not evaluated in our study and there is a need for studies conducted on a higher number of patients using a higher number of parameters.

The effect of obesity on trauma is multifactorial and varies with age, severity of trauma and localization. Based on our study, one can say that subcutaneous fat accumulation in the abdomen may be a risk factor for complicated hip fractures.

\section{References}

1. Arbabi S, Wahl WL, Hemmila MR, Kohoyda-Inglis C, Taheri PA, Wang SC. The Cushion Effect. J Trauma 2003;54:1090-3.

2. Backstrom IC, MacLennan PA, Sawyer JR, Creek AT, Rue III LW, Gilbert SR. Pediatric Obesity and Traumatic Lower Extremity Long Bone Fracture Outcomes. J Trauma Acute Care Surg 2012;73:966-71.

3. Rana AR, Michalsky MP, Teich S, Groner JI, Caniano DA, Schuster DP. Childhood obesity: a risk factor for injuries observed at a level-1 trauma center. J Pediatr. Surg 2009;44:1601-5.

4. Brown CV, Neville AL, Salim A, Rhee P, Cologne K, Demetriades D. The impact of obesity on severely injured children and adolescents. J Pediatr Surg 2006;41:88-91. 
5. Brown CVR, Neville AL, Rhee P, Salim A, Velmahos GC, Demetriades D. The impact of obesity on the outcomes of 1, 153 critically injured blunt trauma patients. J Trauma 2005;59:1048-51.

6. Byard RW, Langlois NE. Letter to the editor-Increasing body weight of motorcycle riders. J Forensic Sci 2011;56:1661.

7. Riggs BL, Melton LJ. The worldwide problem of osteoporosis: Insights afforded by epidemiology. Bone 1995;17:505-11.

8. Joakimsen RM, Magnus JH, Fønnebø V. Physical activity and predisposition for hip fractures. a review. Osteoporos Int 1997;7:503-13.

9. Chiron P, Lafontan V, Reina N. Fracture-dislocations of the femoral head. Orthop Trauma Surg Research 2013;99:53-66.

10. Henle P, Kloen P, Siebenrock KA. Femoral head injuries: which treatment strategy can be recommended? Injury Int J Care Injured 2007;38:478-88.

11. Beckmann NM, Chinapuvvula NR, Cai C. Association of femoral head and acetabular fractures on computerized tomography: correlation with the Judet-Letournel classification. Emerg Radiol 2017;24:531-9.

12. Kim J, Lim H, Lee SI, Kim YJ. Thickness of Rectus Abdominis Muscle and Abdominal Subcutaneous Fat Tissue in Adult Women: Correlation with Age, Pregnancy, Laparotomy, and Body Mass Index. Arch Plast Surg 2012;39:528-33.

13. Pi-Sunyer FX. The obesity epidemic: pathophysiology and consequences of obesity. Obes Res 2002;10:97-104.

14. Wang Y, Lobstein T. Worldwide trends in childhood overweight and obesity. Int J Pediatr Obes 2006;1:11-25.

15. Liu HT, Rau CS, Wu SC, Chen YC, Hsu SY, Hsieh HY, et al. Obese motorcycle riders have a different injury pattern and longer hospital length of stay than the normal-weight patients. Scand J Trauma Resusc Emerg Med 2016;24:50.

16. Finucane MM, Stevens GA, Cowan MJ, Danaei G, Lin JK, Paciorek CJ, et al. National, regional, and global trends in bodymass index since 1980: systematic analysis of health examination surveys and epidemiological studies with 960 country-years and 91 million participants. Lancet 2011;377:557-67.

17. Stevens GA, Singh GM, Lu Y, Danaei G, Lin JK, Finucane MM, et al. National, regional, and global trends in adult overweight and obesity prevalences. Popul health metrics 2012;10:22.

18. Chuang JF, Rau CS, Kuo PJ, Chen YC, Hsu SY, Hsieh HY, et al. Traumatic injuries among adult obese patients in southern Taiwan: a cross-sectional study based on a trauma registry system. BMC Public Health 2016;16:275.

19. Dimitri P, Bishop N, Walsh JS, Eastell R. Obesity is a risk factor for fracture in children but is protective against fracture in adults: A paradox. Bone 2012;50:457-66.

20. Kim SJ, Ahn J, Kim HK, KimJH. Obese children experience more extremity fractures than nonobese children and are significantly more likely to die from traumatic injuries. Acta Pædiatrica 2016;105:1152-7.

21. Davidson PL, Goulding A, Chalmers DJ. Biomechanical analysis of arm fracture in obese boys. J Paediatr Child Health 2003;39:657-64.

22. Pomerantz WJ, Timm NL, Gittelman MA. Injury patterns in obese versus nonobese children presenting to a pediatric emergency department. Pediatrics 2010;125:681-5.
23. Witt CE, Arbabi S, Nathens AB, Vavilala MS, Rivara FP. Obesity in pediatric trauma. J Pediatr Surg 2017;52:628-32.

24. Vaughan N, Tweed J, Greenwell C, Notrica DM, Langlais CS, Peter SD, et al. The impact of morbid obesity on solid organ injury in children using the ATOMAC protocol at a pediatric level I trauma center. J Pediatr Surg 2017;52:345-8.

25. Hasanoglu A, Bideci A, Cinaz P, Tumer L, Unal S. Bone mineral density in childhood obesity. J Pediatr Endocrinol Metab 2000;13:307-11.

26. Goulding A, Taylor RW, Jones IE, McAuley KA, Manning PJ, Williams SM. Overweight and obese children have low bone mass and area for their weight. Int J Obes Relat Metab Disord 2000;24:627-32.

27. Haricharan RN, Griffin RL, Barnhart DC, Harmon CM, McGwin G. Injury patterns among obese children involved in motor vehicle collisions. J. Pediatr. Surg 2009;44:1218-22.

28. Honkanen RJ, Honkanen K, Kroger H, Alhava E, Tuppurainen M, Saarikoski S. Risk factors for perimenopausal distal forearm fracture. Osteoporos Int 2000;11:265-70.

29. De Laet C, Kanis JA, Odén A, Johanson H, Johnell O, Delmas $\mathrm{P}$, et al. Body mass index as a predictor of fracture risk: A metaanalysis Osteoporos Int 2005;16:1330-8.

30. Joakimsen RM, Fønnebø V, Magnus JH, Tollan A. Søgaard AJ. The Tromsø Study: Body Height, Body Mass Index and Fractures. Osteoporos Int 1998;8:436-42.

31. Cummings SR, Nevitt MC, Browner WS, Stone K, Fox KM, Ensrud KE, et al. Risk factors for hip fracture in white women. Study of Osteoporotic Fractures Research Group. N Engl J Med 1995;332:767-73.

32. Gnudi S, Sitta E, Lisi L. Relationship of body mass index with main limb fragility fractures in postmenopausal women. J Bone Miner Metab 2009;27:479-84.

33. Holmberg AH, Johnell O, Nilsson PM, Nilsson J, Berglund G, Akesson K. Risk factors for fragility fracture in middle age. A prospective population-based study of 33,000 men and women. Osteoporos Int 2006;17:1065-77.

34. Hla MM, Davis JW, Ross PD, Wasnich RD, Yates AJ, Ravn P, et al. Multicenter study of the influence of fat and lean mass on bone mineral content: evidence for differences in their relative influence at major fracture sites. Am J Clin Nutr 1996;64:354-60.

35. Greenspan SL, Myers ER, Maitland LA, Resnick NM, Hayes WC. Fall severity and bone mineral density as risk factors for hip fracture in ambulatory elderly. JAMA 1994;271:128-33.

36. Morris BJ, Richards JE, Guillamondegui OD, Sweeney KR, Mir HR, Obremskey WT, et al. Obesity Increases Early Complications After High-Energy Pelvic and Acetabular Fractures. Orthopedics 2015;38:881-7.

37. Neville AL, Brown CV, Weng J, Demetriades D, Velmahos GC. Obesity Is an Independent Risk Factor of Mortality in Severely Injured Blunt Trauma Patients. Arch Surg 2004;139:983-7.

38. Ryb GE, Dischinger PC. Injury severity and outcome of overweight and obese patients after vehicular trauma: a crash injury research and engineering network (CIREN) study. J Trauma 2008;64:406-11. 